\title{
4
}

\section{THRIVING IN AN UNFRIENDLY TERRITORY}

\section{The peculiar rise of minipublics in consociational Belgium}

\section{Julien Vrydagh, Sophie Devillers, Vincent Jacquet, David Talukder and Jehan Bottin}

\subsection{Introduction}

Representative democracies are under huge pressures due to the growing disillusion toward their institutions and their main actors. Belgium is not an exception to this general trend in industrialized countries. To face this challenge, several scholars and political actors propose to bring citizens back into political systems. They intend to foster opportunities for unorganized citizens to take part in deliberation about public goods and to influence decision-making beyond electoral periods (Dryzek et al., 2019). One of the most popular deliberative and participatory innovations is the deliberative minipublic, a generic appellation for citizens' juries, consensus conferences, or citizens' assemblies (Smith, 2009). These forums bring together a group of citizens that deliberate on a political issue, listen to stakeholders' and experts' testimonies, and subsequently formulate a set of policy recommendations. Minipublic participants are recruited through a process of random selection to establish a sample of citizens with diversified backgrounds (Carson \& Martin, 1999).

For decades, Belgium has been described as a copybook example of a consociational State (Deschouwer, 2012; Lijphart, 2012). Elites of each subgroup monopolized the governmental decision-making that inhibited the development of more direct citizen participation. For ten years, we are nevertheless witnessing a remarkable increase of democratic innovations, especially deliberative minipublics. Some pundits have even presented the country at the forefront of the spread of participatory and deliberative mechanisms (OECD, 2020). A couple of initiatives have attracted a lot of academic and media attention as the grassroot G1000 which aimed to gather a thousand people during the political crisis of 2011 (Reuchamps et al., 2017) or the Parliament of the Germanspeaking community that established a permanent randomly selected assembly 
(Niessen \& Reuchamps, 2019). But is Belgium really exceptional? And if so, what makes it exceptional?

This chapter first presents an overview of minipublics that took place in Belgium between 2001 and 2019 and discusses the particularities of Belgium with respect to deliberative minipublics. We demonstrate that, while Belgian minipublics share many common traits with the rest of the world, they are atypical for two reasons. On the one hand, they tend to be convened at higher levels of authority. On the other hand, several cases have recently been institutionalized. Next, we suggest explanations that account for this new trend of institutionalization, especially the structural elements and the action of specific groups campaigning in favor of the implementation of minipublics.

\subsection{An overview of minipublics in Belgium between 2001 and 2019}

To capture Belgian particularities regarding deliberative minipublics, we rely on an innovative data collection project-the Belgian Minipublics Project (BMP) - which documents 43 minipublics that took place in Belgium between 2001 and 2019 (Vrydagh et al., 2020). ${ }^{1}$ Although there exist international data collection projects on minipublics (OECD, 2020; see also the website Participedia), none has successfully mapped cases to a certain completeness. ${ }^{2}$ Therefore, we do not have access to data allowing us to compare all the BMP's listed characteristics. The BMP database counts 43 deliberative minipublics for the 2001-2019 period. We provide a complete overview of these cases in the appendix (Table A.4.1). Our selection criteria, including a minipublic in the database, were threefold: (1) participants should be randomly selected, (2) the participatory process must feature a deliberative dimension, and (3) participants must exclusively be inhabitants of Belgium. ${ }^{3}$

\subsubsection{The design characteristics of minipublics}

Minipublics can take different forms with respect to the number of participants and the length. Regarding the former, minipublics are often subject to criticisms for involving only a very limited number of participants, thereby not constituting a truly participatory process (Chambers, 2009; Lafont, 2019). As shown in Figure 4.1, Belgian minipublics do not escape this criticism as only 2634 people in total have fully participated, that is an average of 61.2 participants per process (45.9 without the G1000 extreme value). A large majority of minipublics (28 cases, 65.1\%) gather fewer than 41 citizens. Only ten cases $(23.2 \%)$ have seen between 41 and 100 people deliberate, while only five cases (11.6\%) count more than 101 participants. A quick comparison with the OECD database seems to indicate that Belgium organizes more frequently smaller minipublics (fewer than 40 participants), but this difference is more likely to be the result of the data collection process. ${ }^{4}$ However, one Belgian minipublic stands out due to its attendance: 


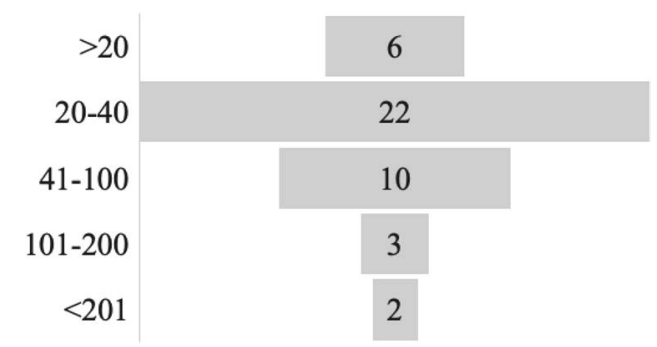

FIGURE 4.1 The number of participants of Belgian minipublics between 2001 and 2019

the G1000. With 704 participants, this minipublic has generated a lot of public attention and put in the spotlight the ideas of citizen deliberation and random selection. Its design was innovative, and, to date, no other cases were implemented on a similar scale. The literature even has created a category in their typology of minipublics to capture the G1000 (Setälä \& Smith, 2018). As we will explain next, this singular case has played a substantial role in making Belgium an exceptional country with respect to its minipublics.

Regarding the length, Belgian minipublics do not seem to show exceptional characteristics. The literature indicates that the length can vary between one and ten days, and even up to 20-30 for Citizens' Assemblies (Elstub, 2014; OECD, 2020; Setälä \& Smith, 2018). The Belgian case features a similar diversity as illustrated by Figure 4.2. Almost half of them (21 cases; 48.8\%) last less than three days. Whereas minipublics lasting four or five days are less common (five cases; $11.6 \%$ ), those lasting six or seven days (i.e. roughly three weekends) are more frequent with twelve cases (27.9\%). Finally, we count four minipublics that last

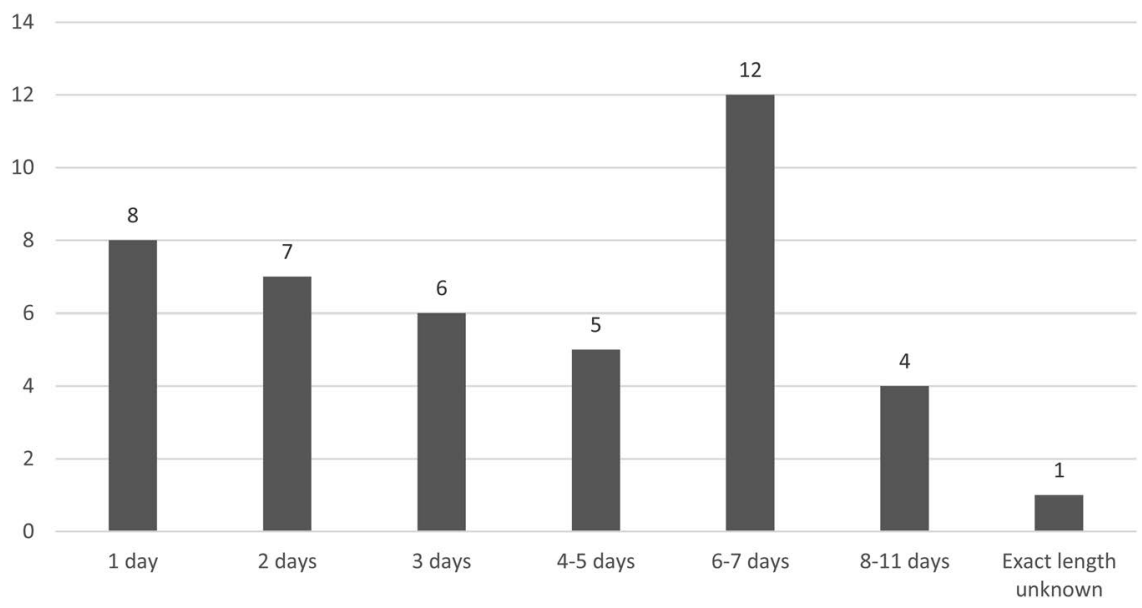

FIGURE 4.2 The length of Belgian minipublics between 2001 and 2019 
between eight and eleven days (9.3\%), while we did not find the precise length of a minipublic that lasted around ten days.

\subsubsection{Minipublics' themes}

Minipublics deal with a great variety of topics (OECD, 2020, pp. 73-77), and Belgian minipublics make no exception. Figure 4.3 shows a series of broad categories in which we classified the topics they discussed. The most common topic is the territory with $18.6 \%$, followed by the environment with $13.9 \%$ and health-related issues with $11.6 \%$. Other popular topics consist of generational issues ${ }^{5}$ and mobility (four cases, 9.6\% each), the education, and the European Union (three cases, 7\% each). Three minipublics also feature an open agenda (7\%). Finally, we see a great diversity (25.3\%) of themes ranging from science and research or radicalization to consumption and social cohesion.

\subsubsection{Level of government}

The implementation of minipublics beyond the local level seems at first sight unlikely in Belgium. As previously mentioned, the Belgian federal level tends to function as an exclusive arena for political elites, wherein the citizens' direct involvement is scarce and discouraged (Deschouwer, 2012). Moreover, the academic literature points out that minipublics - and other processes of citizen participation - tend to be initiated at the local level (Dahl, 1994; Font et al., 2018, p. 629; for an exception, see Pogrebinschi, 2013). The OECD report confirms

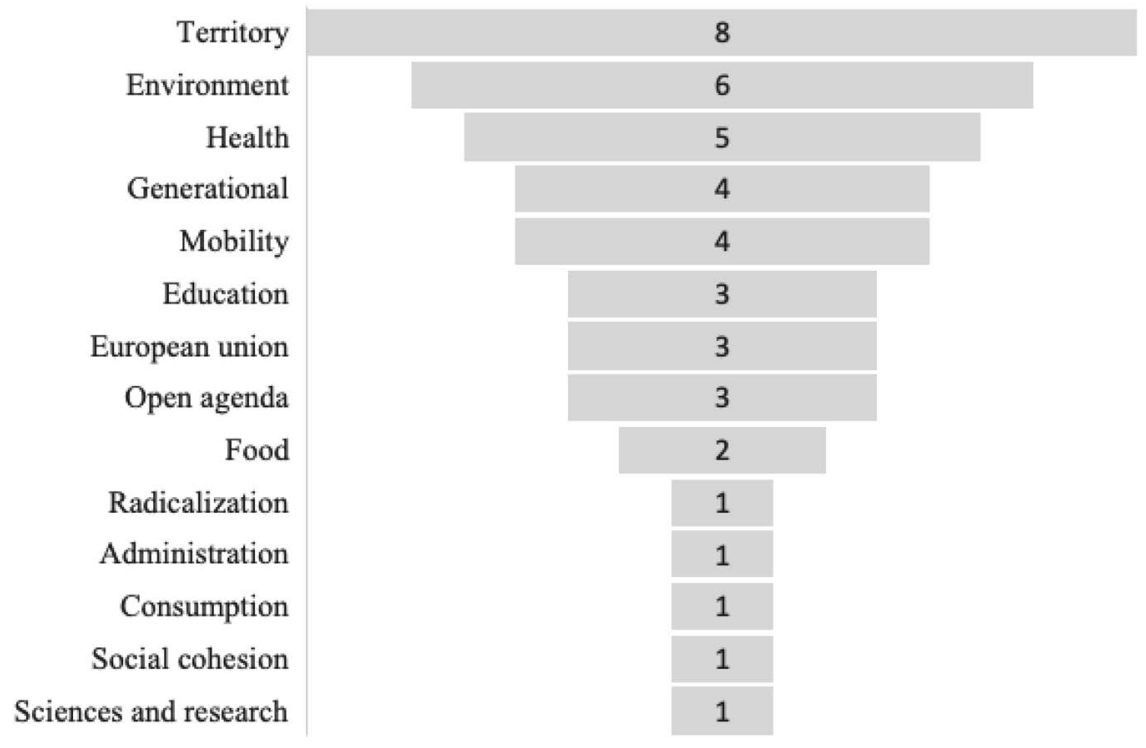

FIGURE 4.3 The themes of Belgian minipublics between 2001 and 2019 


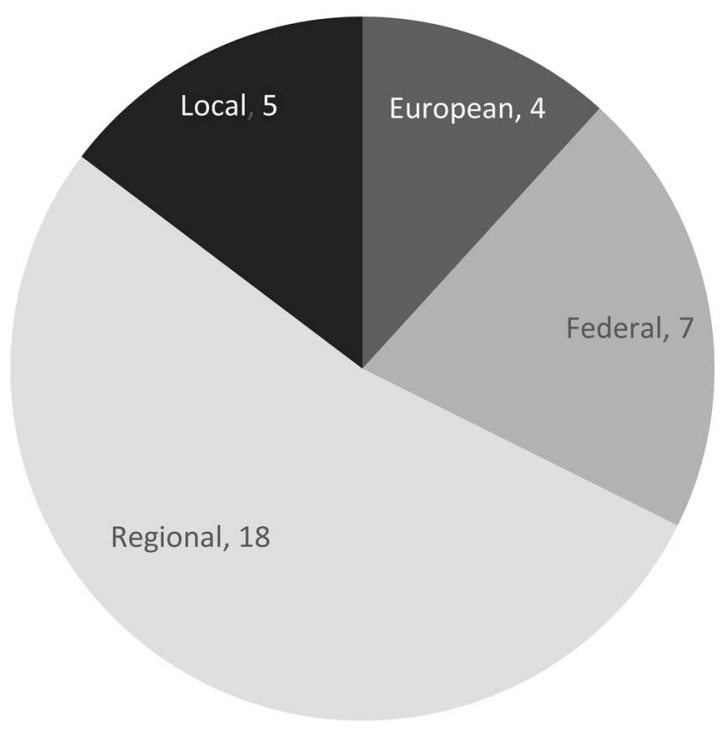

FIGURE 4.4 The level of government of Belgian minipublics' initiators between 2001 and 2019

this general trend, as a majority of minipublics tend to be carried out at the local level: $52 \%$ were implemented at the local level, $30 \%$ at the regional level, $15 \%$ at the national or federal level, and 3\% at the international level (OECD, 2020, pp. 69-70). ${ }^{6}$ Yet, despite these international findings, our data demonstrate the opposite. Figure 4.4 shows most Belgian minipublics are organized at the regional or federal level and deal with competencies belonging to these levels of authority.

We distinguish here two variables: the level of government of a minipublic's initiator and the level of authority to which the minipublic's issue relates. ${ }^{7}$ Our data indicate that only a minority of minipublics involved local authorities or issues. Regarding the initiators' level of authority, ${ }^{8}$ most minipublics were either organized at the regional ${ }^{9}(18$ cases, $41.9 \%)$ or federal level $(7$ cases, $16.3 \%)$, whereas local authorities only convene five minipublics (11.6\%). The European Union has also organized a few minipublics (four cases, 9.3\%), but this finding is more likely to be the result of our selection criteria rather than a confirmation of our theoretical expectations. ${ }^{10}$

In addition, most of the issues under deliberation (18 cases, 41.9\%) also relate to a regional level of authority. The federal level is the second most common one with ten cases (23.2\%), followed by the local level with seven cases $(16.3 \%)$. Figure 4.5 suggests that Belgian minipublics seem to depart from the general trends identified in the academic literature and the OECD's large comparative study: minipublics are not in majority organized at the local level but at the regional level and they regularly deal with federal and-sometimes-European issues. 


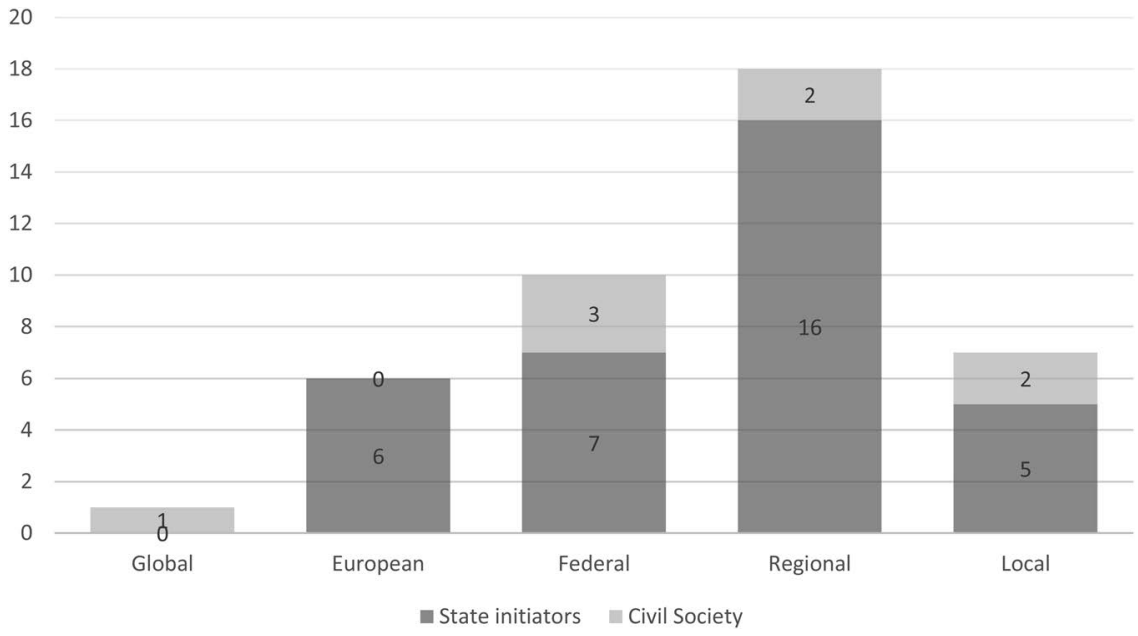

FIGURE 4.5 The level of authority of minipublics' issues in Belgium between 2001 and 2019

\subsubsection{Evolution of minipublics}

When we look at the evolution of minipublics in Belgium in Figure 4.6, we can distinguish two phases. First, we see a steady rise of minipublics between 2001 and 2016. The annual number of minipublics oscillates between zero and four and yields an average of 1.6. The second phase-between 2017 and 2019-is shorter but features a considerable increase in cases, almost half of the entire database (18 cases, $41.9 \%$ ). The annual average scores 6.5 and reaches a maximum of eight cases in 2017 and a minimum of five occurrences. This two-step evolution is difficult to put in a comparative perspective, but the general trend identified in the OECD report tends to follow a similar dynamic (OECD, 2020, p. 69).

If Belgium does not seem to depart from the main trends of the OECD report regarding the evolution of the number of minipublics organized over the years, why is Belgium presented at the forefront of this movement (OECD, 2020)? The answer does not lie here in the numbers but in the kinds of minipublics that have been implemented since 2019. Indeed, while it is complex to categorize minipublics based on ancient original designs, such as citizen juries, consensus conference, or planning cells (Elstub, 2014; Setälä \& Smith, 2018; see Vrydagh et al., 2020 for an example of categorization of these models on cases), we are witnessing in Belgium a trend of institutionalizing minipublics.

On February 25th, the Parliament of the German Community of Belgium is the first Parliament to institutionalize a 'Permanent Citizen Dialogue' (Niessen \& Reuchamps, 2019). Next, on December 13th, the Parliament of the Region of Brussels Capital and of the Common Assembly of the Common Community 


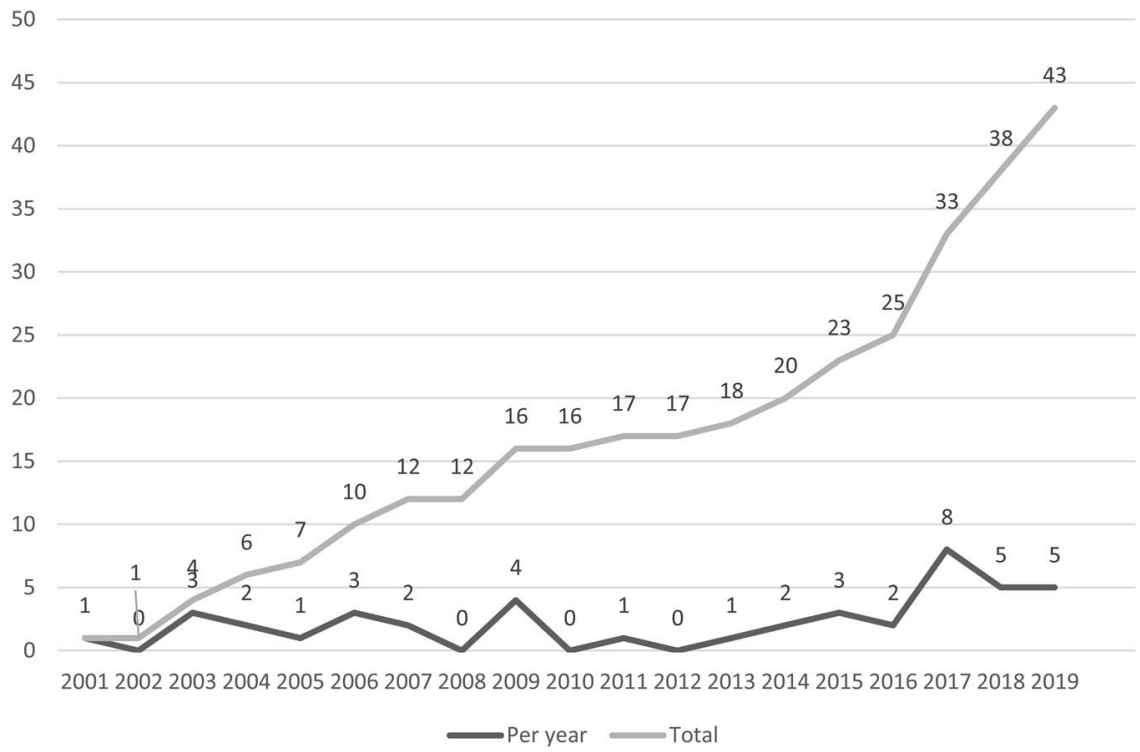

FIGURE 4.6 Evolution of minipublics in Belgium between 2001 and 2019

Commission modified their internal regulation to create the Deliberative Citizens' Commissions composed of randomly selected citizens and elected representatives (Vrydagh et al., 2021). Finally, the Parliament of the Walloon Region has also integrated a Deliberative Citizens' Commission in their internal regulation. ${ }^{11}$

Besides these initiatives at the regional level, we observe that institutionalized minipublics are mushrooming at the local level too, especially in urban areas. In the region of Brussels, the municipalities of Auderghem, Brussels City, Etterbeek, and Saint-Gilles have institutionalized minipublics in the form of Neighborhood Councils that provide advice to the elected council and/or comanage processes of participatory budgets. In Flanders, the municipality of Mechelen has also institutionalized a Citizens' Cabinet that provides the city council with recommendations.

Belgium is of course not the only place where minipublics are institutionalized. The city of Madrid institutionalized an Observatorio de la Ciudad in which 49 randomly Madrilenian citizens deliberated to send citizen proposals on a referendum and to monitor the municipality's actions (Smith, 2020). ${ }^{12}$ Nevertheless, what makes Belgium exceptional is the speed and the range of this institutionalizing trend. Whereas other cases of institutionalization tend to be singular and isolated, Belgium has seen multiple cases of institutionalization at different levels of government in less than three years. Starting from this exceptional characteristic, the next section suggests explanations accounting for this sudden and broad rise of minipublics. 


\subsection{Dynamics fostering or hindering the rise of minipublics in Belgium}

At first glance, the development of democratic innovations in Belgium might appear surprising. Indeed, citizen participation has been very marginal until the beginning of the 21st century due to the consociational nature of the Belgian State and the Royal Question trauma. Belgium is typically described as a textbook example of a consociational State (Caluwaerts \& Reuchamps, 2020; Deschouwer, 2012; Lijphart, 1968). This kind of political system, relying on compromises between elites of all segments of society, has emerged to maintain the country united and peaceful, despite its religious, linguistic, and socioeconomic divides. This system is said to be able to secure the State stability as long as citizens remain passive and elites govern on their own (Huyse, 1970). A greater involvement of citizens would therefore severely complicate the consensusbuilding process and undermine the political stability (O'Leary, 2005). Furthermore, the consultation on the return of the King (called The Royal Question) after World War II dramatically divided the country between Flemish and Walloon citizens, almost leading to a civil war (Caluwaerts \& Reuchamps, 2020).

Despite this context, we are currently observing the spread of minipublics, and even some cases of institutionalization at the local and regional levels. Two crucial elements seem to have shaped the growth of deliberative minipublics in the Belgian political system: the progressive construction of a network of advocates for democratic innovations and the development of a political offer on participatory democracy.

\subsubsection{A network of advocates}

A network of actors progressively acted as a lobby in favor of opening up the political system to new forms of citizen participation. Although this network has no formal structure, it grew stronger and larger and contributed to setting the issue of participatory and deliberative democracy on the Belgian political agenda. A key actor is the G1000 platform, which brings together activists and academic researchers that are committed to deliberative democracy (Caluwaerts \& Reuchamps, 2018). In 2011, this grassroots organization set up a minipublic as a response to the political crisis that led Belgium to break the length record of a State without a functioning government. Thanks to an important communication campaign, with famous public figures as spokespersons such as David Van Reybrouck-author of the book 'Against the elections' (2013), the G1000 succeeded in attracting a lot of political and media attention on the virtues of citizen deliberation and sortition. It acted as a catalyst for a group of actors who later formed a network committed to the implementation of democratic innovations in Belgium. The platform also counts among its ranks important foundations, like the Foundation for Future Generations or the King Baudouin Foundation. 
Other foundations and associations are also campaigning for advancing the use of minipublics, as La Maison du Peuple d'Europe, Periferia, Présence et Action Culturelles, and Reboot Democracy/Agora. Despite the heterogeneous nature of the various innovations they promote, ${ }^{13}$ they contributed to put the notions of public participation, random selection, and deliberation on the political agenda. Most of these organizations are 'deliberative activists', but a blurry line distinguishes those that lobby with a benevolent purpose from those that canvass to generate revenue. For the last ten years, we are indeed witnessing a significant increase of operators (such as Particitiz, CitizenLab, Fluicity, Atanor, Tree company or Tr@me) that are specialized in the design and implementation of citizen deliberation and are developing a 'participatory democracy market' (Lee, 2015; Mazeaud \& Nonjon, 2018). These businesses' services entail proposals for organizing a one-shot process (e.g. minipublics on a specific issue) and longer processes (e.g. participatory budgets of a neighborhood), or for setting up an online platform. These informal networks of advocates have played an important role in convincing a growing number of actors that minipublics are an appropriate solution to the malaise affecting representative democracies. They also helped popularize in Belgium some international minipublics, such as the Irish Citizens' Assembly (Farrell \& Suiter, 2019).

\subsubsection{The political offer regarding participatory and deliberative democracy}

As suggested in our comparative overview, public authorities are the main organizers of minipublics. Some political actors and political parties have indeed accompanied the development of democratic innovations, including deliberative minipublics. This suggests that, despite Belgium's consociational tradition, political leaders have progressively endorsed the development of citizen deliberation and participation. As a matter of fact, whereas there were only a few mentions of democratic innovations in party manifestos for the 2010 elections, the subsequent manifestos contained significantly more calls for implementing deliberative and participatory processes (Jacquet et al., 2016). This trend was further amplified in the 2019 elections, with almost all parties developing proposals to increase citizens' participation in decision-making (Pascolo, 2020). How can we explain this evolution?

First, the political system's consociational nature is declining because the Belgian classical segmental divisions (pilarisation/verzuiling) seem increasingly less relevant (Caluwaerts \& Reuchamps, 2020). Belgian citizens seem less faithful to these segments and their traditional intermediate institutions, e.g. the Church (Papadopoulos, 2013). Some citizens claim for other models of democracy in which they could be politically active without intermediate institutions (Blondiaux, 2008).

Along the same line, political leaders increasingly feel that the electoral model of democracy experiences a malaise. Levels of party affiliation are at 
an all-time low (van Haute \& Gauja, 2015), and we observea rise of abstention and blank and null votes (Biard et al., 2019; Pilet et al., 2019), as well as vote switching (Talukder et al., 2021), while trust in elected representatives is plummeting (Goovaerts et al., 2019). Overall, more citizens are becoming dissatisfied with the current system of representative democracy and are calling for alternatives (Caluwaerts et al., 2017). Political elites seem to be aware of this dissent and are therefore increasingly seeking to reform the political system to create new participation channels (Bedock, 2017). In 1994, popular consultations were allowed at the local and provincial level and, since 2019, at the regional level. The mushrooming of minipublics also seems to be a way for political elites to address citizens' dissatisfaction. They often evoke the crisis of representative democracy as a motive of their organization. As suggested by Macq and Jacquet (2020), the leaders of the German-Speaking community that established Belgium's first permanent minipublic fundamentally conceive the new institution as a way to restore the broken link between elected representatives and the population. They hope that discussions with randomly elected citizens will show that making public decision is a complex enterprise subject to many constraints, which they think ordinary citizens often fail to understand. Accordingly, German-speaking political leaders hope that this new assembly will help to restore trust in traditional representative institutions and actors.

However, all parties do not have the same attitudes toward randomly selected assemblies. In general, left-wing parties tend to be more supportive of these reforms (Gourgues, 2013; Herzog, 2016; Lawrence et al., 2009; Lovenduski \& Norris, 1993; Scarrow, 1999). In the Belgian context, the two green parties were among the first to integrate the notion of citizens' participation into their manifestos, as early as the 1990s (Biard et al., 2020). They have since then pushed an agenda for democratic reforms through, inter alia, minipublics. They were notably the two main advocates for the mixed parliamentary committee in the Brussels and the Walloon Regions and they successfully implemented these reforms when they joined the government of these two federal entities. In regard of these experiences, the multiple institutional reforms toward more federalism seem to have opened new avenues for citizen participation and minipublics, because it is easier for smaller political parties to join governmental coalition where they can implement their political programs. In Flanders, the green political party Groen also tried in 2017 to institutionalize minipublics with a Citizens' Assembly bill, but it was the only party that voted in favor of the bill. The lack of support from other political parties does not mean that they all, at least explicitly, oppose minipublics. Actually, the whole Flemish Parliament voted the same day in favor of a nonbinding resolution asking the Flemish Government to engage "in 'participatory experiments' and to actively include citizens in policy discussion" (Van Crombrugge, 2020, p. 68).

More generally, it is important to underline that contemporary Belgian political leaders remain balanced toward the development of democratic innovations. 
Both qualitative and quantitative research shows that members of the different parliaments (MPs) of the country support consultative minipublics (Jacquet et al., 2020; Rangoni et al., 2021). They view these deliberative participatory processes to enrich the representative linkage. However, when it comes to decision-making power, MPs are much less supportive. The very large majority of MPs considers randomly selected assemblies should not receive the authority to make binding decision. To put it simply, democratic innovations are valuable as long as they do not interfere with the power of current decision makers and citizens' voice remains consultative.

\subsection{Conclusion}

This chapter intended to explain the rise of minipublics in Belgium. We first described the state of minipublics to identify what makes Belgium exceptional. Our comparative overview of 43 minipublics shows that Belgian minipublics are similar to the international trends with respect to its design and its topics, but they feature exceptional characteristics regarding the level of government where they are convened. Despite an unlikely institutional context and the assumptions in the literature, only a minority of minipublics were convened at the local level, while a majority was organized at the regional and federal levels. The most uncommon characteristic is, however, the recent series of institutionalization of minipublics, which followed an increase in the number of minipublics starting in 2017. Almost half of all Belgian minipublics were implemented between 2017 and 2019. The institutionalization trend started in 2018 and has seen several institutionalized minipublics at the local and regional levels.

The second part of the chapter aimed to explain this exceptional growth of (institutionalized) minipublics. First, we suggest that Belgium has a strong informal network of diverse actors that lobby in favor of minipublics. Second, we analyzed the public offer of political parties and public authorities. Although Belgium is known for its consociationalist system that initially seems incompatible with citizen participation, we propound different factors explaining the success of minipublics in this unlikely setting. The declining relevance of consociationalism in parallel with declining levels of trust toward institutions and politics correlate with the development of a political offer for citizens' participation. Furthermore, the recent institutional reforms toward more federalism seem to open new venues for minipublics, especially at the regional level.

This chapter primarily sought to open a reflection rather than provide definitive answers. Future research is necessary not only to test empirically these hypotheses but also to formulate others. Indeed, we have just scratched the surface of the explanations of the rise of minipublics in Belgium. Among other potentially relevant explanations, we could have mentioned the role of public officials who were involved in a minipublic organization and became convinced by the process and are now canvassing in their own administration and political cabinets. The notorieties of international minipublics, like the Irish Citizens' 
Assembly or the recent French Climate Convention on the Climate, have shown Belgian leaders and citizens that minipublics could be implemented on salient and sensitive political issues at a high level of government. Finally, while we welcome projects of cross-country data collections, we also want to call for data collection projects that seek to list exhaustively minipublics in one country. Such databases are crucial if we aspire to conduct more in-depth comparative analysis between countries and to explore in more detail how different countries contribute to the global rise of minipublics.

\section{Notes}

1 We adopt a three-level methodological approach to identify minipublics. First, we searched on the Web and in the national, regional, and local media with a series of terms related to minipublics. Second, we sent a list with our cases to Belgian municipalities, practitioners, and scholars specialized in participatory and deliberative democracy to consolidate our list and find other cases that we may have missed. Finally, we sent our cases' descriptions to minipublics' organizers and initiators in order to be sure that everything was well reported. The database of Vrydagh et al. (2020) ends in 2018, so we completed it with the data of 2019 for this chapter. We do not include cases from 2020 because the COVID-19 prevented the start or the continuation of several minipublics.

2 For instance, the impressive OECD data collection has identified only four cases of minipublics in Belgium between 2001 and 2019, whereas the BMP project has listed 35 cases matching the OECD's selection criteria.

3 As a consequence, we do not consider deliberative minipublics organized by international organizations, such as the European Union, that involve citizens from other countries.

4 During our data collection process (Vrydagh et al., 2020), we have realized that small and - often local-minipublics tend to go under the radar. It is thus likely that a larger cross-countries data collection project does not have the resources or the local knowledge necessary to spot these less reachable minipublics.

5 Generational entails issues such as the youth or the elderly.

6 As we previously pointed out, the proportion of minipublics at the local level is likely to be larger because it is more difficult to find them.

7 For instance, the Walloon regional Parliament initiated the minipublic 'Quelle Europe pour demain' (2017) during which citizens deliberated on the European Union. This case thus belongs to the European category.

8 This thus excludes the eight minipublics initiated by the civil society. The percentage displayed in this section is based on the entire population of the database.

9 Regional authority consists of the regional authorities of Flanders, Wallonia, Brussels, the communitarian authorities of the French- and German-speaking communities, and the provinces.

10 We selected minipublics whose participants were exclusively inhabitants of Belgium.

11 Walloon Parliament, "Modification du Règlement du Parlement de Wallonie visant à consacrer la constitution de commissions délibératives entre députés et citoyens tirés au sort", approved on October 282020.

12 The Observatorio de la Ciudad has, however, been dismantled in early 2020 by the next right-wing local government (La Vanguardia, 2020).

13 Some organizations, such as Kayoux, promote the random selection of candidates on local elections lists and the organization of citizen panels at the local level, while others, such as the political party Agora, organize regional minipublics to address recommendations to the Brussels Parliament. There are also organizations, like the Burgerlobby, that advocate for the institutionalization of minipublics and the end of the Belgian coalition system. 
14 The first round of the permanent Bürgerrat had 10 meetings. The handover to the new one happened on the tenth encounter, and the new Bürgerrat is now meeting again.

\section{References}

Bedock, C. (2017). Reforming Democracy: Institutional Engineering in Western Europe (New product edition). Oxford: Oxford University Press.

Bedock, C., Rangoni, S., \& Talukder, D. (2019). How MP's Perceive Deliberative and Participatory Democracy: An Inquiry into the French-Speaking Belgian Case. Conference Democratic Renewal in Times of Polarisation. The Case of Belgium, p. 1-29.

Biard, B., Blaise, P., Faniel, J., Istasse, C., \& Sägesser, C. (2019). Les résultats des élections régionales et communautaires du 26 mai 2019. Courrier hebdomadaire du CRISP 2414-2415(9): 5-138.

Biard, B., Bottin, J., Cogels, M., \& Sabbe, M. (2020). Ecologists and Democracy in Belgium: An Analysis of Party Manifestos. Working Paper Series-COST Action Constitution-Making and Deliberative Democracy.

Blondiaux, L. (2008). Le nouvel esprit de la démocratie: Actualité de la démocratie participative. Paris: Seuil.

Caluwaerts, D., Biard, B., Jacquet,V., \& Reuchamps, M. (2017). What is a Good Democracy? Citizens' Support for New Modes of Governing. In K. Deschouwer (Ed.), Mind the Gap: Political Participation and Representation in Belgium. Colchester: ECPR Press, pp. 75-89.

Caluwaerts, D., \& Reuchamps, M. (2018). The Legitimacy of Citizen-Led Deliberative Democracy: The G1000 in Belgium. London: Routledge.

Caluwaerts, D., \& Reuchamps, M. (2020). Still Consociational? Belgian Democracy, 50 Years After 'The Politics of Accommodation'. Politics of the Low Countries 2(1): 28-50.

Carson, L., \& Martin, B. (1999). Random Selection in Politics. Westport: Greenwood Publishing Group.

Chambers, S. (2009). Rhetoric and the Public Sphere: Has Deliberative Democracy Abandoned Mass Democracy? Political Theory 37(3): 323-350.

Dahl, R.A. (1994).A Democratic Dilemma: System Effectiveness Versus Citizen Participation. Political Science Quarterly 109(1): 23-34.

Deschouwer, K. (2012). The Politics of Belgium: Governing a Divided Society. London: Macmillan International Higher Education.

Dryzek, J., Bächtiger, A., Chambers, S., Cohen, J., Druckman, J., Felicetti, A., Fishkin, J. S., Farrell, D., Fung, A., Gutmann, A., Landemore, H., Mansbridge, J. J., Marien, S., Neblo, M., Niemeyer, S., Setälä, M., Slothuus, R., Suiter, J., Thompson, D., \& Warren, M. (2019). The Crisis of Democracy and the Science of Deliberation. Science 363(6432): 1144-1146.

Elstub, S. (2014). Mini-Publics: Issues and Cases. In S. Elstub \& P. McLaverty (Eds.), Deliberative Democracy: Issues and Cases. Edinburgh: Edinburgh University Press, pp. 166-188.

Farrell, D. M., \& Suiter, J. (2019). Reimagining Democracy: Lessons in Deliberative Democracy from the Irish Front Line. Ithaca, NY: Cornell University Press.

Font, J., Smith, G., Galais, C., \& Alarcon, P. (2018). Cherry-Picking Participation: Explaining the Fate of Proposals from Participatory Processes: Cherry-Picking Participation. European Journal of Political Research 57(3): 615-636.

Goovaerts, I., Kern, A., van Dijk, L., van Haute, E., \& Deschouwer, K. (2019). Communiqué de presse. Vote protestataire ou idéologique. Les déterminants des choix électoraux au 26 mai 2019. Note sur base des données du projet EoS RepResent. Brussel: EOS RepResent.

Gourgues, G. (2013). Les politiques de démocratie participative. Grenoble: Presses universitaires de Grenoble. 
Herzog, O. (2016). Representatives' Support for Direct Democracy: Intrinsic Policy-Seeking or Just a New Instrument of Power-Seeking? Prague: ECPR General Conference.

Huyse, L. (1970). Passiviteit, pacificatie en verzuiling in de Belgische politiek: Een sociologische studie. Leuven: Standaard Wetenschappelijke Uitgeverij.

Jacquet, V., Moskovic, J., Caluwaerts, D., \& Reuchamps, M. (2016). The Macro-Political Uptake of the G1000 in Belgium. In M. Reuchamps, \& J. Suiter (Eds.), Constitutional Deliberative Democracy in Europe. Colchester: ECPR Press, pp. 53-74.

Jacquet,V., Niessen, C., \& Reuchamps, M. (2020). Sortition, Its Advocates and Its Critics: An Empirical Analysis of Citizens' and MPs' Support for Random Selection as a Democratic Reform Proposal. International Political Science Review, Online first: 1-22.

La Vanguardia (2020, February 25). Madrid elimina el Observatorio de la Ciudad heredado de Carmena. La Vanguardia. (website: https://www.lavanguardia.com/politica/20200225/ 473776329838/madrid-elimina-el-observatorio-de-la-ciudad-heredado-de-carmena. html)

Lafont, C. (2019). Democracy without Shortcuts: A Participatory Conception of Deliberative Democracy. Oxford: Oxford University Press.

Lawrence, E. D., Donovan, T., \& Bowler, S. (2009). Adopting Direct Democracy: Tests of Competing Explanations of Institutional Change. American Politics Research 37(6): 1024-1047.

Lee, C. W. (2015). Do-It-Yourself Democracy: The Rise of the Public Engagement Industry. Oxford: Oxford University Press.

Lijphart,A. (1968). Typologies of Democratic Systems: Comparative Political Studies 1(1): 3-44. Lijphart, A. (2012). Patterns of Democracy. New Haven, London:Yale University Press.

Lovenduski, J., \& Norris, P. (1993). Gender and Party Politics. Thousand Oaks, CA: Sage.

Macq, H., \& Jacquet, V. (2020). The Politics of Citizens' Assemblies: Why Political Leaders Establish Participatory and Deliberative Institutions, 'One Year of Permanent Citizens' Dialogue in the German-Speaking Community of Belgium' Workshop, 21 September 2020.

Mazeaud, A., \& Nonjon, M. (2018). Le marché de la démocratie participative.Vulaines sur Seine: Editions du Croquant.

Niessen, C., \& Reuchamps, M. (2019). Le dialogue citoyen permanent en Communauté germanophone. Courrier hebdomadaire du CRISP 2426(21): 5-38.

OECD (2020). Innovative Citizen Participation and New Democratic Institutions: Catching the Deliberative Wave. Paris: OECD.

O'Leary, B. (2005). Debating Consociational Politics: Normative and Explanatory Arguments. In S J R Noel (Ed.), From Power Sharing to Democracy: Post-Conflict Institutions in Ethnically Divided Societies. Montreal: McGill-Queen's Press, pp. 3-43.

Papadopoulos, Y. (2013). Democracy in Crisis?: Politics, Governance and Policy. UK: Macmillan Education.

Pascolo, L. (2020). Do Political Parties Support Participatory Democracy? A Comparative Analysis of Party Manifestos in Belgium. Working Paper Series-COST Action ConstitutionMaking and Deliberative Democracy, 9.

Pilet, J.-B., Sanhueza, M. J., Talukder, D., Dodeigne, J., \& Brennan, A. E. (2019). Opening the Opaque Blank Box:An Exploration into Blank and NullVotes in the 2018 Walloon Local Elections. Politics of the Low Countries 1(3): 182-204.

Pogrebinschi, T. (2013). The Squared Circle of Participatory Democracy: Scaling Up Deliberation to the National Level. Critical Policy Studies 7(3): 219-241.

Rangoni, S., Bedock, C., \& Talukder, D. (2021). More competent thus more legitimate? MPs' discourses on deliberative mini-publics. Acta Politica. 
Reuchamps, M., Caluwaerts, D., Dodeigne, J., Jacquet,V., Moskovic, J., \& Devillers, S. (2017). Le G1000: une experience citoyenne de démocratie deliberative. Courrier Hebdomadaire $d u$ CRISP 2344-2345(19-20): 5-104.

Scarrow, S. E. (1999). Parties and the Expansion of Direct Democracy. Party Politics 5(3): 341-362.

Setälä, M., \& Smith, G. (2018). Mini-Publics and Deliberative Democracy. In A. Bächtiger, J. S. Dryzek, J. Mansbridge \& M. Warren (Eds.), The Oxford Handbook of Deliberative Democracy. Oxford: Oxford University Press, 300-314.

Smith, G. (2009). Democratic Innovations: Designing Institutions for Citizen Participation. Cambridge: Cambridge University Press.

Smith, G. (2020). Institutionalizing Deliberative Mini-Publics in Madrid City and German Speaking Belgium-The First Steps. Constitutionnet, Http://Constitutionnet.Org/News/ Institutionalizingdeliberative-Mini-Publics-Madrid-City-and-German-SpeakingBelgium-First, Accessed on, 10.

Talukder, D., Uyttendaele, L., Jennart, I., \& Rihoux B. (2021). The Impact of VAAs on Vote Switching at the 2019 Belgian Legislative Elections: More Switchers, but Making Their Own Choices. Politics of the Low Countries 3(1): 73-94.

Van Crombrugge, R. (2020). The Derailed Promise of a Participatory Mini-Public: The Citizens' Assembly Bill in Flanders. Journal of Deliberative Democracy 16(2): 63-72.

van Haute, E., \& Gauja, A. (2015). Party Members and Activists. London: Routledge.

Van Reybrouck, D. (2013). Tegen verkiezingen. Amsterdam: De Bezige Bij.

Vrydagh, J., Devillers, S., Talukder, D., Jacquet, V., \& Bottin, J. (2020). Les mini-publics en Belgique (2001-2018): expériences de panels citoyens délibératifs. Courrier Hebdomadaire du CRISP 2477-2478(32-33): 5-72.

Vrydagh, J., Bottin, J., Reuchamps, M., Bouhon, F., \& Devillers, S. (2021). Les commissions délibératives entre parlementaires et citoyens tirés au sort au sein des assemblées bruxelloises. Courrier Hebdomadaire du CRISP 2492(7): 5-68. 
TABLE A.4.1 An overview of minipublics in Belgium (2001-2019)

\begin{tabular}{|c|c|c|c|c|c|}
\hline Minipublic & Date & Level of authority & Participants & Length & Theme \\
\hline Quel Brabant Wallon pour demain & 2001 & Regional & 62 & 3 & Territory \\
\hline Lire dans mes genes & 2003 & Federal & 30 & 7 & Health \\
\hline Des OGM au champ & 2003 & Federal & 17 & 2 & Environment \\
\hline Publiek forum-GMOs & 2003 & Regional & 16 & 9 & Environment \\
\hline Sécurité alimentaire: à quel prix? & 2004 & Federal & 30 & 2 & Food \\
\hline Panel Citoyen sur les droits des consommateurs & 2004 & Federal & 30 & 2 & Consumption \\
\hline Meeting of minds & $2005-2006$ & European & 21 & 6 & Health \\
\hline Panel citoyen-Plan IRIS II & 2006 & Regional & 30 & 4 & Mobility \\
\hline J'inspire ma Ville... Bruxelles Capital Santé & 2006 & Regional & 21 & 10 & Environment \\
\hline Nos campagnes, demain en Europe & 2006 & Regional & 35 & 6 & Territory \\
\hline Citizens' perspectives on the Future of Europe & 2007 & European & 132 & 3 & European Union \\
\hline Burgerconventie-Auto en gezondheid & 2007 & Regional & 224 & 1 & Mobility \\
\hline World Wide Views & 2009 & International & 100 & 1 & Environment \\
\hline European Citizens' Consultation in Belgium & 2009 & European & 49 & 2 & European Union \\
\hline $\begin{array}{l}\text { Citizen Visions on Science, Technology and } \\
\text { Innovation }\end{array}$ & $2009-2010$ & European & 11 & 2 & $\begin{array}{l}\text { Sciences and } \\
\text { technology }\end{array}$ \\
\hline Radioactive Waste Management Plan & 2009-2010 & Federal & 32 & 6 & Environment \\
\hline G1000 & $2011-2012$ & Federal & 704 & 9 & Open agenda \\
\hline Notre future & 2013 & Federal & 24 & 6 & Generational \\
\hline Labocitoyen & 2014 & Federal & 32 & 9 & Health \\
\hline G100 Grez-Doiceau & 2014 & Local & 50 & 1 & Open agenda \\
\hline Parlement Citoyen Climat & 2015 & Provincial & 33 & 6 & Environment \\
\hline Ouderpanel & 2015-2016 & Regional & 22 & 6 & Education \\
\hline Climacteurs & 2015 & Regional & 55 & 1 & Environment \\
\hline Excellence de l'enseignement en débat citoyen & 2016 & Regional & 24 & 6 & Education \\
\hline Canal Citoyen & 2016 & Local & 30 & 1 & Territory \\
\hline
\end{tabular}


We are Molenbeek

Panel citoyen sur les enjeux de vieillissement Panel Citoyen sur l'extension de l'Esplanade

Gents Burgerkabinet-mobiliteitsplan

Fabrique de liens Citoyens-Verviers

Quelle Europe pour demain

Panel Citoyen sur la petite enfance

Make Your Brussels Mobility

Conférence du Consensus-Pacte D'excellence

Panel Citoyen sur les jeunes en Wallonie

Panel Citoyen sur la propreté publique-Enghien

Mon ADN: tous concernés

Make My administration

Agora-Assemblée citoyenne sur le logement

Panel Citoyen-SOL Louvain La Neuve

Ostbelgien-Bürgerrat

Ostbelgien-Bürgerversalmmungen-Health

Agora citoyenne sur la forêt

$\begin{array}{ccccl}2017 & \text { Local } & 112 & 1 & \text { Radicalization } \\ 2017 & \text { Regional } & 27 & 3 & \text { Generational } \\ 2017 & \text { Local } & 98 & 1 & \text { Territory } \\ 2017-2018 & \text { Local } & 9,50 & 3 & \text { Mobility } \\ 2017-2019 & \text { Local } & 1 & 5 & \text { Social cohesion } \\ 2017 & \text { Regional } & 83 & 2 & \text { European Union } \\ 2017 & \text { Regional } & 22 & 3 & \text { Generational } \\ 2017 & \text { Regional } & 38 & 4 & \text { Mobility } \\ 2018 & \text { Regional } & 116 & 1 & \text { Education } \\ 2018 & \text { Regional } & 27 & 4 & \text { Generational } \\ 2018 & \text { Local } & 15 & 3 & \text { Territory } \\ 2018 & \text { Federal } & 29 & 6 & \text { Health } \\ 2018 & \text { Federal } & 46 & 2 & \text { Administration } \\ 2019-2020 & \text { Regional } & 60 & 7 & \text { Housing } \\ 2019 & \text { Local } & 25 & 7 & \text { Territory } \\ 2019-2020 & \text { Regional } & 24 & 10^{14} & \text { Open agenda } \\ 2019-2020 & \text { Regional } & 16 & 4 & \text { Health } \\ 2019-2020 & \text { Provincial } & 31 & 6 & \text { Territory }\end{array}$




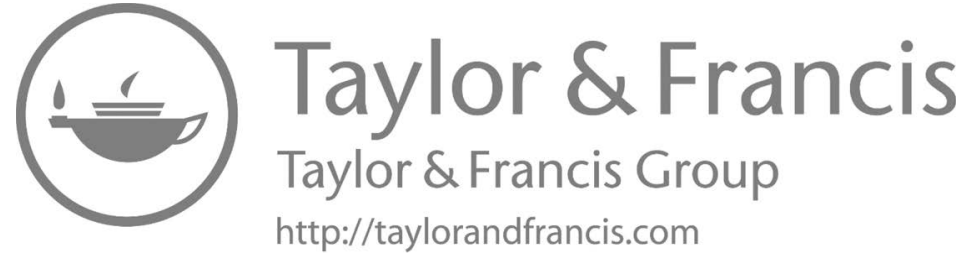

